УДК 346, 349.6

DOI https: / / doi.org/10.32837/yuv.v0i6.2036

\author{
В. Малолітнева, \\ кандидат юридичних наук, \\ учений секретар \\ Інституту економіко-правових досліджень імені В.К. Мамутова \\ Національної академії наук України
}

А. Гурова,

кандидат юридичних наук,

науковий співробітник

Інституту держави і права імені В.М. Корецького Національної академії наук України

\title{
ПРАВОВІ ЗАСАДИ ВИКОРИСТАННЯ ДАНИХ ДИСТАНЦІЙНОГО ЗОНДУВАННЯ ЗЕМЛІ ЯК ДОКАЗІВ У ВІТЧИЗНЯНОМУ СУДОЧИНСТВІ ДЛЯ ЗАХИСТУ ОБ'ЄКТІВ АРХЕОЛОГІЧНОЇ СПАДЩИНИ ${ }^{1}$
}

Постановка проблеми. Використання аерокосмічних засобів дистанційного зондування Землі (далі - ДЗ3) допомагає отримувати інформацію, яка забезпечує можливість спостереження за станом об'єктів археологічної спадщини, факторами, що впливають на них, оцінювати та використовувати їх як докази в суді.

Відповідно до ст. 1 Закону України «Про топографо-геодезичну і картографічну діяльність», дистанційне зондування Землі - це процес отримання даних про поверхню Землі методом аерофотозйомки або шляхом спостереження і вимірювань із космосу [1]. Слід відзначити, що настільки широке розуміння джерел отримання даних Д3З не кореспондує їх міжнародно-правовому тлумаченню відповідно до Резолюції ГА $\mathrm{OOH} 41 / 65$ «Принципи стосовно дистанційного зондування Землі 3 космосу», згідно зі ст. 1 якої термін «дистанційне зондування» означає зондування поверхні Землі з космосу 3 використанням властивостей електромагнітних хвиль, що випромінюються, відображаються або розсіюються зондованими об'єктами, задля кращого розпорядження природними ресурсами, удосконалення землекористування та охорони навколишнього середовища. Такий вузький підхід до розуміння даних ДЗ3 як таких, що не охоплюють аерофотозйомку, відображений у підготовленому Державним космічним агентством України проєкті Закону України «Про державне регулювання у сфері дистанційного зондування Землі» таким чином: дистанційне зондування Землі 3 космосу - це отримання даних про Землю з космосу з використанням властивостей електромагнітних хвиль, випромінюваних, відбиваних, поглинутих чи розсіюваних об'єктами відбивання. Проте цей законо-

1 Роботу підготовлено у межах Програми НАН України «Гранти НАН України дослідницьким лабораторіям/групам молодих вчених НАН України для проведення досліджень за пріоритетними напрямами розвитку науки і техніки 2020-2021 pр.» за темою наукового проєкту «Правові та організаційні аспекти використання аерокосмічної зйомки для дослідження й охорони археологічної спадщини України», а саме його етапу 1 «Міжнародно-правові засади і зарубіжний досвід організації використання дистанційного зондування Землі та аерокосмічної зйомки для дослідження й охорони археологічної спадщини. Сучасний стан правового регулювання і організації використання дистанційного зондування та аерокосмічної зйомки для дослідження й охорони археологічної спадщини в Україні». 
проєкт, незважаючи на десятирічну історію розроблення та обговорення, навряд чи буде прийнятий у такій редакції, тому поки що тлумачення поняття «ДЗЗ» та створюваних у його результаті продуктів $€$ невизначеним у контексті колізії норм міжнародного космічного права та положень національного законодавства. Це впливає негативно на визначення даних ДЗ3 як джерела доказу.

Огляд останніх досліджень. Окремі аспекти набуття юридичного значення даними ДЗЗ та властивості, притаманні доказам у судових процесах, досліджували такі вітчизняні та зарубіжні науковці, як T. Баранова, М. Бек, Н. Малишева, O. Ткаченко, C. Candelmo, K. Geer, S. Mosteshar, V. Nardone. Водночас комплексне розуміння правових засад використання даних ДЗЗ як доказів у вітчизняному судочинстві для захисту об'єктів археологічної спадщини ще не склалося, тому це становить мету нашого дослідження.

Виклад основного матеріалу. Культурна та археологічна спадщина часто стають об'єктами охорони в судовому засіданні незалежно від юрисдикції. Так, у цивільному судочинстві доволі поширеними $€$ позови щодо заборони вчинення неправомірних дій та приведення земельної ділянки історико-культурного значення у попередній стан [2] або стосовно визнання недійсними рішеннями державних актів на право власності на земельну ділянку договору купівлі-продажу земельної ділянки цього ж призначення [3]. У ст. 92 Кодексу про адміністративні правопорушення України серед порушень вимог законодавства про охорону культурної спадщини визначено проведення ремонтних, реставраційних, реабілітаційних робіт на пам'ятці культурної спадщини, зміну призначення пам'ятки культурної спадщини, їх частин та елементів, здійснення написів, позначок на ній, на іï території та в ї охоронній зоні без письмового дозволу відпо- відного органу охорони культурної спадщини; порушення режиму використання пам'ятки культурної спадщини. Крім того, цим Кодексом також передбачено відповідальність за порушення правил використання земель, що може безпосередньо стосуватися земель історико-культурного призначення, адже під час будівництва доріг, ліній електропередач і зв'язку, об'єктів соціально-культурного призначення, житла тощо пам'ятки археології першими потрапляють у «зону ризику» [4, с. 94]. У Кримінальному кодексі України окреслено одне кримінально каране діяння у сфері охорони археологічної та культурної спадщини, передбачене ст. 298, яке, однак, містить декілька об’єктів (археологічної і культурної спадщини) та об'єктивних сторін: незаконне проведення археологічних розвідок, розкопок, інших земляних чи підводних робіт на об'єкті археологічної спадщини; умисне незаконне знищення, руйнування або пошкодження об'єктів культурної спадщини чи їх частин. Крім того відповідний склад кримінального правопорушення включає декілька таких кваліфікуючих обставин:

1) пам'ятка національного значення як предмет;

2) мета пошуку рухомих предметів, що походять із об'єктів археологічної спадщини як елемент суб'єктивної сторони;

3) службова особа 3 використанням службового становища як спеціальний суб'єкт [5].

Всі ці обставини стають предметами доказування в тому чи іншому судовому провадженні, а джерелом доказів стають дані ДЗЗ.

Нині в Україні вже є певна практика використання космічних знімків у суді як доказу, переважно це стосується знімків з Google Earth. Втім, ця практика $€$ неоднозначною, можна знайти кардинально різні підходи суддів до таких доказів. В одних випадках суд оцінює роздруківки фотогра- 
фій земельної ділянки за допомогою Google Earth Pro як допустимий доказ [6], у інших - ні [7]. Ці складнощі на практиці значною мірою обумовлені певними недоліками у правовому регулюванні відносин у сфері використання даних Д3З, перш за все космічних знімків, та порядку ix поширення, що може негативно впливати на допустимість знімків як доказів, що з огляду на їх значну потенційну роль у встановленні наявності або відсутності певних обставин (фактів) потребує особливої уваги.

Вирішення питання про допустимість доказу справляе найбільш відчутний вплив на законність судового рішення. Допустимість проявляється у таких двох аспектах [8, с. 93]: негативний, коли правом окремі докази визнаються недопустимими, наприклад такі, що одержані з порушенням закону (відповідно до ст. 74 Кодексу адміністративного судочинства України (далі - КАС України) [9], ст. 77 Господарського процесуального кодексу України (далі - ГПК Україн) [10], ст. 78 Цивільного процесуального кодексу України (далі - ЦПК України) [11], ст. 86 Кримінального процесуального кодексу України (далі - КПК України) [12], суд не бере до уваги докази, які одержані з порушенням порядку, встановленого законом); позитивний, коли відповідні обставини можуть бути підтверджені певними засобами доказування (згідно з ч. 2 ст. 74 КАС України, ст. 77 ГПК України, ст. 78 ЦПК України, обставини, які за законом мають бути підтверджені певними засобами доказування, не можуть підтверджуватись іншими засобами доказування).

Слід почати з того, що інформація, отримана за допомогою ДЗЗ, грунтується на даних, які збираються, записуються та зберігаються електронним способом. Відповідно до ст. 99 КАС України та КПК Україн, до електронних доказів належать електронні документи, які включають i графічні зображення, і фотографії.
Отже, з формулювання статті випливає, що космічні знімки виступають електронним документом. Електронна природа такої інформації сама по собі не впливає на допустимість доказів [13]. Втім, відповідно до Закону України «Про електронні документи та електронний документообіг», електронний документ повинен мати обов'язкові реквізити, серед яких слід назвати електронний цифровий підпис (далі - ЕЦП). Більш того, відповідно до ч. 6 ст. 43 ЦПК України, ч. 5 ст. 42 ГПК України, електронні документи подаються до суду з використанням Єдиної судової інформаційно-телекомунікаційної системи шляхом заповнення форм процесуальних документів, що нині не може бути повністю реалізовано внаслідок проблем із технічним функціонуванням відповідної системи.

Таким чином, щоб суд міг прийняти космічний знімок як доказ для його оцінки, на ньому має бути ЕЦП. Наприклад, у справах № 922/788/19 [14] та № 922/1151/18 [15] Верховний Суд у складі колегії суддів Касаційного господарського суду зазначив, що роздруківка електронного листування без електронного підпису не може вважатись електронним документом в розумінні ч. 1 ст. 5 Закону України «Про електронні документи та електронний документообіг», відповідно до якої електронний документ - це документ, інформація в якому зафіксована у вигляді електронних даних, включаючи обов'язкові реквізити документа, а електронний підпис є обов'язковим реквізитом електронного документа, який використовується для ідентифікації автора та/або підписування електронного документа іншими суб'єктами електронного документообігу. Накладання електронного підпису завершує створення електронного документа, тобто космічний знімок має бути посвідчений ЕЦП. В контексті перебування на розгляді у Верховній Раді України законопроєктів «Про віртуальні активи» [16] 
та «Про токенізовані активи та криптоактиви» [17] слід зазначити, що електронний підпис $є$ фактично аналогією приватного ключа, який також отримується за результатами криптографічного перетворення набору електронних даних, додається до цього набору або логічно з ним поєднується, накладається за допомогою особистого ключа й дає змогу підтвердити його цілісність та ідентифікувати підписувача за допомогою відкритого (публічного) ключа [18, с. 25]. Таким чином, зі створенням правового поля для використання системи блокчейну запис у ній може бути прирівняний до ЕПЦ та слугувати підтвердженням достовірності доказу.

У контексті допустимості доказів космічні знімки мають певні переваги перед іншими видами даних Д33, зокрема знімками, отриманих 3 дистанційно пілотованих повітряних суден (дронів), адже якщо будуть порушені вимоги використання дрону під час зйомки, то знімок може бути визнаний недопустимим внаслідок його отримання способом, що порушує законодавство (Тимчасовий порядок використання повітряного простору України від 31 травня 2018 р. Державної авіаційної служби) [19]. Нині використання дронів масою більше 2 кг підпадає під певні заборони/обмеження використання повітряного простору. Наприклад, польоти дронів масою до 2 кг виконуються тільки вдень. Для дронів масою більше 2 кг необхідно дотримуватись вимог щодо подання заявок на використання повітряного простору та за потреби отримати відповідні дозволи від Повітряних сил 3С України, органів Державної прикордонної служби України, органів об'єднаної цивільно-військової системи організації повітряного руху України, органів обслуговування повітряного руху та управління повітряним рухом тощо [20], тобто в разі порушень умов, визначених у Тимчасовому порядку, знімки, отримані з дронів, можуть бути визнані недопустимими як доказ.
Однак певні проблеми можуть виникати щодо допустимості також космічних знімків як доказу.

Щодо позитивного аспекту допустимості доказів стосовно космічних знімків слід у кожному випадку визначати, чи відсутні загальні заборони використовувати такий засіб доказування на підтвердження відповідних обставин. Загалом слід зазначити, що все більше на рівні законодавства України використання даних ДЗЗ визнається як засіб моніторингу, розкриття порушень та запобігання ним. Наприклад, відповідно до Постанови КМУ «Про затвердження Положення про державну систему моніторингу довкілля» від 30 березня 1998 р. № 391, на Державне космічне агентство України покладено обов'язок здійснювати моніторинг стану територій за даними дистанційного зондування Землі [21]; згідно з Постановою КМУ «Про затвердження Положення про Державну екологічну інспекцію України» від 19 квітня 2017 р. № 275, Держекоінспекція для виконання покладених на неї завдань має право здійснювати відповідно до закону фотографування, звукозапис, кіноі відеозйомку, зокрема 3 літальних апаратів та із застосуванням космічних технологій, як допоміжний засіб для запобігання порушенням законодавства та їх розкриття, здійснення нагляду (контролю) за додержанням якого належить до повноважень Держекоінспекціі.

Щодо негативного аспекту допустимості доказу щодо даних ДЗЗ слід зазначити такі складові частини, які можуть вплинути на цю властивість доказу.

За принципами щодо дистанційного зондування Землі з космосу, будь-яка держава, міжнародна організація чи суб'єкт господарювання може робити космічну зйомку території будь-якої держави та надавати їх на недискримінаційній основі та розумних умовах оплати [22]. Таким чином, режим поширення космічних знімків сто-

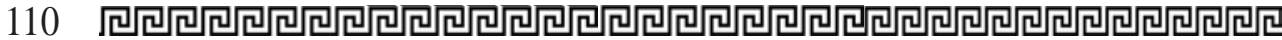


совно своєї території може визначати лише держава, до юрисдикції якої належать оператори, що здійснюють космічну зйомку, а також суб’єкти, що обробляють закуплені або іншим чином отримані в іноземних операторів космічні знімки відповідно до потреб споживачів.

Оскільки Україна не має власних супутників, актуальним питанням нині постає саме порядок набуття та поширення космічних знімків високої просторової роздільної здатності, зокрема дистриб'юторами даних, отриманих 3 іноземних космічних апаратів. До потенційних проблем, які можуть вплинути на допустимість знімків як доказу і деякі з яких потребують більш детального врегулювання на законодавчому рівні, можна віднести такі.

1) Потенційне порушення прав людини i громадянина, зокрема йдеться про втручання у право на особисте життя [23]. У цьому контексті $€$ цікавим зарубіжний досвід. Наприклад, у Німеччині справа Федерального Конституційного суду стосувалась фотографій будинку відомої особи, які були отримані за допомогою камери 3 гелікоптеру. Суд встановив, що права особи на приватне життя порушуються, якщо фото власності, яка не є доступною для громадськості, публікуються у прив'язці до адреси або іншої інформації, за допомогою якої можна визначити мешканця, тобто за таких обставин це стосується знімків з супутників. У 2008 та 2009 рр. Конституційний суд установив, що певні автоматичні відеозаписи щодо контролю за швидкістю на дорозі порушують право людини вирішувати, коли i в яких межах інформація про іï особисте життя має бути передана іншим особам, що ставить під питання використання таких записів як доказів. Однак право на інформаційне самовизначення має бути збалансованим із публічними інтересами, такими як безпека на дорогах. У 2010 р. Суд установив, що за цих обставин докази 3 камер контролю за швидкістю, визначені законодавством, можуть бути використані [24, с. 156].

Відповідно до Закону України «Про захист персональних даних», персональними даними вважаються відомості чи сукупність відомостей про фізичну особу, яка ідентифікована або може бути конкретно ідентифікована, тобто Закон захищає лише інформацію, яка належить особі, що може бути ідентифікована. Таким чином, навряд чи цим регулюванням можуть охоплюватись дані ДЗ3, навіть якщо ї було отримано без згоди особи, якщо за ними не можна іiі ідентифікувати. В іншому випадку, відповідно до зарубіжного досвіду, наприклад, коли знімок будинку дає змогу визначити, як дістатись будинку у прив'язці до географічних даних, та ідентифікувати особу, яка там мешкає, це вже буде порушенням порядку обробки персональних даних. Так, у Німеччині поява у Google функціï перегляду вулиць (Google Street View) спричинила багато дискусій, що мало наслідком угоду між відповідними органами влади, які були відповідальними за питання персональних даних, та компанією Google, коли громадяни Німеччини отримали право вимагати розмиття фотографій своїх будинків або підприємств, щоб запобігти їхьої ідентифікації [25; 27, с. 334]. Деякі автори зазначають, що знімки з просторовою роздільною здатністю, яка не перевищує 40 см, вважаються такими, що не розкривають персональну інформацію, втім, потрібен аналіз у кожному окремому випадку [24, с. 157]. У США раніше існувала заборона щодо виробництва апаратів Д3З просторового розрізнення менше 50 см, що потім було змінено на 31 см. Наприклад, для компаній-операторів супутників Китаю та Індії такі обмеження не встановлені [23]. Як зазначають C. Candelmo та V. Nardone, у судових позовах щодо захисту прав людини суди повинні думати 
про сумісність із принципами прав людини, коли вони використовують дані Д3З в національних судових процесах, але не говорити лише про причини прийнятності та значення GPS-відстеження та супутникових зображень [26, с. 101]. Саме тому використання даних ДЗЗ у суді як доказів вимагає дотримання таких вимог, як адекватність, достатність та сумісність із правами людини.

2) Потенційне порушення прав на комерційну таємницю. Відповідно до ст. 420 Цивільного кодексу України (далі - ЦК України), до об'єктів права інтелектуальної власності належить комерційна таємниця. Згідно зі ст. 505 ЦК України, комерційною таємницею можуть бути відомості технічного, організаційного, комерційного, виробничого та іншого характеру. Такі відомості можуть бути пов'язані 3 відповідною земельною ділянкою, на якій розташований певний стратегічно важливий об'єкт або технологіі, виробниче обладнання, а поширення космічних знімків про таку ділянку може мати економічний ефект [27, с. 334]. Виключне право дозволяти використання комерційної таємниці належить до майнового права інтелектуальної власності на комерційну таємницю. Таким чином, поширення знімків 3 такою інформацією може потенційно порушувати це право. Оскільки в Україні нині поки не напрацьовано практику поширення та використання космічних знімків як доказу, зокрема в аспекті відповідності законодавству у сфері охорони прав інтелектуальної власності, для більш наочного прикладу порушення таких прав є доцільним звернутись до зарубіжного досвіду.

Найбільш відомою справою, в якій розглядалось це питання, є спір Dow Chemical Company v United States щодо порушення права на комерційну таємницю внаслідок проведення органом контролю перевірки з використанням аерофотозйомки. Це був хімічний завод, на території якого розташовано багато критих будівель, виробничого обладнання на відкритих ділянках та трубопроводів, які можна побачити з повітря. Завод був огороджений по периметру, що обмежує огляд території сторонніми особами. При цьому ним було відмовлено Агентству 3 охорони навколишнього середовища у допуску для проведення перевірки на місці. Внаслідок цього Агентство найняло приватного аерофотографа для фотозйомки об'єкта [27, с. 377]. Завод вважав, що таким чином було порушено конституційне право на заборону необгрунтованих обшуків та комерційну таємницю. Щодо порушення комерційної таємниці Суд зазначив, що законодавство про комерційну таємницю не забороняє всі форми фотографування промислового комплексу, але лише ті, які здійснюються з наміром використовувати комерційну таємницю, яка була розкрита на фотографіi. Таким чином, немає заборони фотографій, зроблених випадковим пасажиром на авіалайнері, або фото, зробленого підприємством, що виробляє карти задля картографування [27, с. 41]. Досить важливо, що Суд звернув увагу на заходи, яких вжив завод задля охорони комерційної таємниці. Ним було наголошено на тому, що польоти літаків над будівлями заводу $€$ звичним явищем, а завод не зробив жодних кроків для захисту від спостереження 3 повітря. Крім того, Суд зазначив, що метою держави було не економічне шпигунство, а саме забезпечення дотримання вимог екологічного законодавства. Використання супутників задля проведення дослідження створює значні переваги для суспільства, яке завдяки цьому може знати про стан виконання законодавства у сфері охорони довкілля. Суд у цьому разі має збалансувати інтереси суспільства та рівень втручання у приватне життя [28, с. 52]. Відповідно до такої позиції, просто факт існування комерційної таємниці на об'єкті, який досліджується, не виключає можливості 
використання інформації, отриманої за допомогою супутників, як доказу [27, с. 41]. Цей досвід цікавий саме в аспекті використання таких даних з боку державних органів влади, втім, не дає відповіді у випадку, коли інформація, що містить комерційну таємницю, використовується приватним суб'єктом.

Таким чином, питання охорони комерційної таємниці під час поширення та використання космічних знімків як доказів мають розглядатись у кожному випадку окремо.

3) Потенційна загроза національним інтересам та порушення державної таємниці. У питанні допустимості даних Д3З, зокрема космічних знімків, як доказів важливим аспектом виступають питання національної безпеки. Національна безпека визначається, зокрема, через захищеність національних інтересів, реалізація яких забезпечує державний суверенітет України, ії прогресивний демократичний розвиток, а також безпечні умови життєдіяльності й добробут їі громадян [29]. Охорона об’єктів археологічної та культурної спадщини підпадає під визначення національних інтересів. В цьому контексті слід згадати положення ст. 31 Закону Украіни «Про охорону культурної спадщини», згідно 3 якою топографічно визначені території чи водні об'єкти, в яких містяться об'єкти культурної спадщини або можлива їх наявність, за поданням відповідного органу охорони культурної спадщини можуть оголошуватися рішенням центрального органу виконавчої влади, що реалізує державну політику у сфері охорони культурної спадщини охоронюваними археологічними територіями на обмежений або необмежений строк у порядку, визначеному Кабінетом Міністрів України. Інформація про ці території може бути віднесена до інформаціі 3 обмеженим доступом відповідно до закону [30]. Серед визначених ст. 21 Закону України «Про інформацію» видів інформа- ції з обмеженим доступом найбільш вірогідно, що вона буде віднесена до таємної чи службової інформації [31], проте порядок віднесення інформації про охоронювані археологічні теритоpii до інформації з обмеженим доступом досі не визначений.

Нині правове регулювання відносин щодо ДЗЗ в Україні є фрагментарним та розпорошеним і є збалансованим лише щодо топографо-геодезичної діяльності [32, с. 224]. Наприклад, ст. 20 Закону України «Про топографо-геодезичну та картографічну діяльність» чітко передбачає під час користування матеріалами Державного картографо-геодезичного фонду України заборону передачі матеріалів аерозйомок, а також матеріалів, що $є$ носіями відомостей, які становлять державну таємницю, організаціям, що не мають належних умов для забезпечення зберігання таких матеріалів. Доступ до матеріалів, що $€$ носіями відомостей, які становлять державну таємницю, здійснюється відповідно до Закону України «Про державну таємницю». Відповідно до ч. 5 ст. 5 Закону України «Про національну інфраструктуру геопросторових даних», базові геопросторові дані не повинні містити відомості, що становлять державну таємницю, та іншу інформацію, доступ до якої обмежений відповідно до закону (інформацію з обмеженим доступом). До речі, розглядаючи це питання, додатково зазначаємо, що, наприклад, у проєкті Закону України «Про топографо-геодезичну і картографічну діяльність» [33] було зроблено уточнення про те, що порядок надання матеріалів і даних Державного фонду геопросторових даних України на запит юридичних та фізичних осіб, у тому числі іноземних, з дотриманням державної та комерційної таємниці затверджується центральним органом виконавчої влади, який реалізує державну політику у сфері топогорафо-геодезичної і картографічної діяльності. Чинний Закон України «Про топо- 
графо-геодезичну та картографічну діяльність» положення про комерційну таємницю прямо не виділяє.

Більш складним питання стає, коли йдеться про дистриб'юторів знімків, адже нині окремо не проводиться перевірка відомостей, які містяться на знімку високої просторової роздільної здатності, що робиться на замовлення третіх осіб на комерційних умовах, а також не визначено на законодавчому рівні, які знімки можна вважати такими, що мають високе просторове розрізнення, тобто фіксований норматив, що має велике значення для правового режиму такої категорії даних ДЗЗ. Наприклад, у Республіці Казахстан, згідно з Правилами планування космічних зйомок, отримання, обробки та розповсюдження даних дистанційного зондування Землі національним оператором космічної системи дистанційного зондування Землі Республіки Казахстан [34], планування космічних зйомок та діяльність, пов'язана з розповсюдженням даних ДЗЗ високого просторового розрізнення, тобто точніше 2 м на місцевості, здійснюється відповідно до вимог законодавства Республіки Казахстан про захист державної таємниці, охорони авторських та суміжних прав, а також умов та обмежень експортного контролю, норм міжнародного права. Законодавство Казахстану у сфері діяльності $з$ ДЗЗ, перш за все щодо поширення ДЗ3, як у США та Німеччині, базується на принципі забезпечення інтересів національної безпеки та оборони [35, с. 135]. Хоча Казахстан має власні супутники, втім, регулюванням охоплюється також поширення даних ДЗЗ дистриб'юторами знімків з іноземних космічних апаратів.

У Німеччині є Закон про безпеку супутникових даних (Satellite Data Security Act), який регулює відносини у сфері використання даних саме високого просторового розрізнення задля захисту національної безпеки. Згідно з цим Законом, німецькі супутники та компаніі, які бажають розповсюджувати дані Д3З високої просторової роздільної здатності (так зване розповсюдження або розкриття даних третім особам вперше) як для комерційних цілей, так і для проведення досліджень, повинні отримати ліцензію. Цей Закон, як правило, не охоплює торгових посередників та типових постачальників послуг Д33. Компанія може продавати дані Д3З високого просторового розрізнення лише тоді, коли таке розповсюдження не порушує національну безпеку Німеччини. Задля цього запроваджено дворівневу систему контролю. 3 урахуванням очікуваної великої кількості запитів на дані Д3З щодня державні органи не матимуть змоги обробляти ефективно кожний запит, що може справити негативний вплив на результат підприємницької діяльності постачальників даних ДЗ3. Таким чином, було запроваджено перший рівень перевірки «чутливості» даних ДЗ3, який здійснює сам постачальник під свою відповідальність, втім, відповідно до чітко встановленої стандартизованої процедури, яка може бути автоматизованою, та критеріїв. Такі критерії включають, наприклад, місцевість, яка досліджується, замовника даних Д33, країну призначення, куди будуть спрямовані дані ДЗ3. Якщо така перевірка класифікує дані ДЗЗ як «нечутливі», постачальник може їх продати замовнику без додаткового розгляду відповідними органами влади. У разі виявлення певних факторів «чутливості» постачальнику даних ДЗЗ забороняється передавати такі дані, однак він може подати заявку відповідним органам влади для переходу на другий рівень перевірки. Таку перевірку у Німеччині здійснює Державна служба експортного контролю (BAFA). Наприклад, у 2018 р. ВАFA видала 1914 дозволів на поширення даних ДЗЗ високого просторового розрізнення [36]. За результатами такої перевірки може бути видано 
дозвіл на передання таких даних ДЗ3 замовнику або заборону. Так званий умовний дозвіл також може бути надано в разі внесення певних змін до замовлення даних ДЗ3, наприклад, щодо меншого просторового розрізнення, нижчої якості оброблення даних або обходу певних ділянок територій, які планується дослідити. Якщо загроза національним інтересам все одно залишається, незважаючи на дотримання цих умов, постачальник не має права передавати дані Д33 [37; 38]. Внаслідок існування такої системи питання національної безпеки не виступають одними з основних питань перед судоми під час використання даних ДЗЗ як доказів [24, с. 157], тобто не ставиться питання про те, чи отримано такий доказ із порушення вимог закону.

У цьому аспекті виникає потреба у державному регулюванні поширення такої інформації, адже в Украіні відсутнє ліцензування в космічній сфері як таке [39, с. 37-44].

Крім допустимості, суд має оцінити доказ ще й з точки зору його достовірності. Відповідно до ст. 75 КАС України, ст. 79 ЦПК України, достовірними $€$ докази, на підставі яких можна встановити дійсні обставини справи, згідно зі ст. 85 КПК України, достовірність $€$ складовою частиною ознаки належності, яка характеризує докази з точки зору підтвердження існування чи відсутності обставин, що підлягають доказуванню; відповідно до ст. 78 ГПК, достовірними є докази, створені (отримані) за відсутності впливу, спрямованого на формування хибного уявлення про обставини справи, які мають значення для справи. Питання про достовірність $є$, як правило, питанням факту, його вирішення не залежить від вимог, установлених законом, адже коли питання достовірності стає питанням права, зазнає впливу правової норми, то воно трансформується у питання допустимості [8, с. 94].

Щодо космічних знімків, то на практиці можуть виникають сумніви щодо їх достовірності, оскільки супутникові зображення зроблені за допомогою машини (техніки), існує можливість збоїв у ї̈ роботі, що збільшує можливості продукувати непослідовні знімки [40]. На певні проблеми вказують у програмному забезпеченні, що створює проблему достовірності отриманих даних та $є$ фактором можливого викривлення отриманих результатів [41]. Знімки із супутника виступають інтерпретацією умов на Землі, адже $є$ знімками, отриманими з алгоритму, який обчислює, яким чином визначаються та візуалізуються «сирі» дані. Іноді це може ускладнювати ситуацію. Наприклад, один розроблений алгоритм, призначений для ідентифікації артилерійських кратерів на супутникових знімках, також визначав місця, схожі на кратери, але які такими не $є$. Для спеціалістів можуть виникати труднощі щодо просіювання інформації, яка дає недосконалі результати [42]. Зображення, отримані із супутника, відрізняються від традиційної фотографії, адже відсутній оригінальний негатив фото, а цифрове фото грунтується на візуальному представленні числових даних. У цьому аспекті знімки із супутника можуть містити певний елемент суб'єктивності, адже дані передаються на Землю у цифровому форматі, що вимагає часто подальшого людського втручання та оброблення для отримання розпізнаваного зображення. Якщо поліпшення та інтерпретація зображень проводяться вручну, такий продукт може мати певні помилки [43, с. 144]. Саме оброблена інформація пропонується як доказ, а не «сирі» дані. Більш того, через певні погодні умови або властивості поверхні не завжди якість зображення може дати можливість оцінити інформацію, яка є на знімку. Для цього необхідно, щоб аерокосмічний знімок супроводжувався появленнями особи, яка володіє спеціальними знаннями у сфері оброблення даних ДЗЗ. 3 цього випливає, що дані ДЗ3 можуть подаватися в судовому процесі у формі 
таких двох доказів: сам аерокосмічний знімок (електронний документ); його опис, у якому на підставі проаналізованих даних ДЗ3 зазначаються параметри, що становлять предмет доказування (місця розкопок, зміна складу покладів під землею, характер руйнування тощо), що вже більше підпадає під ознаки висновку експерта або спеціаліста. Оскільки вище вже було проаналізовано правову природу електронного доказу, то зосередимо увагу на наданні правового значення опису даних ДЗЗ.

У разі подання даних ДЗЗ у вигляді електронного документу, який суд не може оцінити безпосередньо або $€$ сумніви щодо його достовірності, сторона по справі може долучити інший окремий доказ - висновок експерта. Відповідно до ст. 7 Закону України «Про судову експертизу», судово-експертну діяльність здійснюють державні спеціалізовані установи, а також у випадках і на умовах, визначених цим Законом, судові експерти, які не є працівниками зазначених установ. Відповідно до Постанови Пленуму Вищого господарського суду України «Про деякі питання практики призначення судової експертизи» від 23 березня 2012 р. № 4 [44], серед актів законодавства, якими слід керуватись у вирішенні питань призначення судової експертизи в судовому процесі, відзначена Інструкція про призначення та проведення судових експертиз та експертних досліджень та Науково-методичних рекомендацій з питань підготовки та призначення судових експертиз та експертних досліджень, затверджена Наказом Міністерства юстиції України від 8 жовтня 1998 р. № 53/5. Слід відзначити, що серед визначеного в Інструкціï про призначення та проведення судових експертиз та експертних досліджень та Науково-методичних рекомендацій 3 питань підготовки та призначення судових експертиз та експертних досліджень під ознаки діяльності з аналізу даних ДЗЗ лише опосередковано можуть підпадати такі види, як земельно-технічна, експертиза комп'ютерної техніки, експертиза телекомунікаційних засобів і систем, тобто деякі види інженерно-технічної діяльності. Водночас експертизи щодо наявності шкідливих речовин (пестицидів) у навколишньому середовищі; речовин хімічних виробництв та спеціальних хімічних речовин; харчових продуктів; сильнодіючих і отруйних речовин, які належать до криміналістичного виду разом із судово-медичними і судово-психіатричними, відповідно до ч. 3 ст. 7 ЗУ «Про судову експертизу», можуть здійснювати лише в межах державних спеціалізованих установ.

У цьому аспекті виникає доцільність доповнення вищезазначеного переліку експертиз, а також атестаціiі судових експертів, дані про яких містяться у Реєстрі атестованих судових експертів, ведення якого покладається на Міністерство юстиціï України, адже така експертиза потребує саме спеціальних знань, які не можуть охоплюватись лише вищезазначеними видами експертиз. Експерт повинен знати особливості отримання космічних знімків, вміти оцінювати достовірність інформаціï, знати методику їх дослідження. Проведення експертизи є важливим за необхідності проведення комплексних робіт з проведенням польових досліджень, коли потрібно порівняти знімки із самим об'єктом на місці.

$\mathrm{y}$ цьому контексті важливу роль може відіграти спеціаліст, який, відповідно до ст. 70 КАС України, $є$ особою, яка володіє спеціальними знаннями та навичками, необхідними для застосування технічних засобів, і призначена судом для надання консультацій та технічної допомоги під час вчинення процесуальних дій, пов'язаних із застосуванням таких технічних засобів (фотографування, складання схем, планів, креслень, відбору зразків для проведення експертизи тощо). Особливої актуальності 
звернення до спеціаліста набуває тоді, коли роз'яснення змісту знімку не потребує проведення додаткових досліджень, тобто коли проведення саме експертизи не $є$ потрібним. Спеціаліст у адміністративному процесі не складає процесуальних документів, що мають доказове значення. Таким чином, спеціаліст може надавати технічну та консультаційно-довідкову допомогу, сприяти поясненню певних аспектів знімків, які можуть бути зрозумілими й достатніми як окремий доказ без підтримки експертного висновку експерта.

На відміну від адміністративного процесу, відповідно до ст. 71 та ч. 3 ст. 214 КПК України, у кримінальному процесі спеціаліст надає, крім консультацій, висновки, в тому числі до внесення відомостей в Єдиний реєстр досудового розслідування для з'ясування обставин вчинення кримінального проступку. При цьому як експерт, так і спеціаліст несуть відповідальність, встановлену законом, за завідомо неправдивий висновок (ст. 70, ч. 2 ст. 72 КПК).

Водночас юридичні підстави їх діяльності різняться, адже ст. 7-1 ЗУ «Про судову експертизу» підставою проведення судової експертизи визначено судове рішення; рішення органу досудового розслідування; договір з експертом чи експертною установою, якщо експертиза проводиться на замовлення інших осіб. Підставою для отримання висновку спеціаліста $є$ лише запит службової особи підрозділу дізнання органу Національної поліції, органу безпеки, органу, що здійснює контроль за додержанням податкового законодавства, органу Державного бюро розслідувань, Національного антикорупційного бюро України, уповноваженої особи іншого підрозділу зазначених органів, які уповноважені здійснювати досудове розслідування кримінальних проступків.

3 огляду на це можна констатувати, що працівники компаній з оброблення та аналізу даних ДЗЗ та окремі спеціалісти у цій сфері можуть бути залученими до кримінального процесу як спеціалісти, а не отримувати для цього статус експертів, що не працюють у державних експертних установах, адже вони однаково несуть відповідальність, але до спеціалістів не висувається спеціальних вимог щодо атестації та вони можуть бути рідше залучені до процесу внаслідок меншого числа маючих право на таке залучення осіб.

Оскільки нині лише формується ринок виготовлення та аналізу аерокосмічних знімків приватними компаніями, було б доцільно створити перелік акредитованих спеціалістів, який би орієнтував правоохоронні органи щодо отримання спеціальних знань. Відповідний механізм взаємодії було б доцільно передбачити в КПК, щоб мінімізувати ризики визнання таких доказів недопустимими на підставі неврегульованості порядку такої взаємодіï та критеріїв визначення професійної спроможності тих чи інших спеціалістів (ст. ст. 86, 89 КПК України).

Відповідно до ст. 216 КПК, уповноваженими на розслідування кримінального правопорушення, передбаченого ст. 298 KK України, є слідчі органи Національної поліціі, які уповноважені звертатися до спеціалістів для надання відповідних висновків. Водночас слід зазначити, що такими спеціалістами можуть бути не лише приватні суб'єкти, але й спеціально уповноважені органи влади. Так, відповідно до Постанови КМУ від 24 грудня 2019 р. № 1185, право передавати правоохоронним органам матеріали про діяння, в яких вбачаються ознаки кримінального правопорушення, належить Державній інспекції культурної спадщини України (п. 8. ч. 6 Положення) [45]. На відміну від норм цього нормативного акта, П. 8 ч. 6 Постанови КМУ «Про затвердження Положення про Державну екологічну інспекцію України» від 19 квітня 2017 р. № 275, Держекоінспекції для виконання аналогічного 
завдання в екологічній сфері надано право здійснювати відповідно до закону фотографування, звукозапис, кіно- і відеозйомку, зокрема, з літальних апаратів та із застосуванням космічних технологій, як допоміжний засіб для запобігання порушенням законодавства та їх розкриття, здійснення нагляду (контролю) за додержанням якого належить до повноважень Держекоінспекції [46]. Вбачаємо, що закріплення вужчого обсягу прав Державної інспекції культурної спадщини України, по-перше, шкодить єдності правового підходу до визначення прав однорідних за характером виконуваних обов'язків інституцій, по-друге, звужує обсяг засобів щодо охорони об'єктів археологічної та культурної спадщини. 3 огляду на це доцільно передбачити аналогічне положення для Державної інспекції культурної спадщини України.

Підбиваючи підсумок у дослідженні, присвяченому правовим засадам використання даних ДЗЗ як доказів у вітчизняному судочинстві для захисту об'єктів археологічної спадщини, виділяємо такі основні узагальнення та пропозиції:

1) космічний знімок $є$ електронним доказом, зокрема електронним документом, який повинен містити всі необхідні реквізити, які висуваються до таких документів Законом України «Про електронні документи та електронний документообіг»;

2) опис як такий, що допомагає судді шляхом тлумачення космічних знімків з'ясувати обставини справи відповідно до залучення осіб, що володіють спеціальними знаннями, може подаватися у формі висновку експерта або висновку спеціаліста; у цьому контексті доцільно доповнити перелік експертиз, який передбачений Інструкцією про призначення та проведення судових експертиз та експертних досліджень та Науково-методичних рекомендацій з питань підготовки та призначення судових експертиз та експертних досліджень, затвер- дженій Наказом Міністерства юстиції України від 8 жовтня 1998 р. № 53/5, експертизою у сфері ДЗ3, а також слід забезпечити проведення атестації судових експертів, дані про яких містяться у Реєстрі атестованих судових експертів, ведення якого покладається на Міністерство юстиції України.

3) коли зміст космічного знімку можна самостійно встановити, втім, $€$ потреба у додатковому роз'ясненні, без проведення комплексних досліджень можна звернутись за консультативно-довідковою допомогою спеціаліста; крім того, для надання висновку спеціаліста в межах кримінального процесу, було б доцільно створити перелік акредитованих спеціалістів, який би орієнтував правоохоронні органи щодо отримання спеціальних знань; відповідний механізм взаємодії було б доцільно передбачити в КПК, щоб мінімізувати ризики визнання таких доказів недопустимими на підставі неврегульованості порядку такої взаємодії та критеріїв визначення професійної спроможності тих чи інших спеціалістів (ст. ст. 86, 89 КПК України);

4) доведена необхідність більш детального правового регулювання відносин 3 поширення космічних знімків високого просторового розрізнення у контексті охорони комерційної таємниці, персональних даних та національних інтересів, контролю за відомостями, які містяться на знімках, задля недопущення поширення так званих чутливих для держави даних; чіткі правила сприятимуть використанню космічних знімків як доказів з урахуванням їх потенційної ролі, зокрема, у сфері охорони об'єктів археологічної спадщини;

5) обгрунтована необхідність передбачення повноважень Державної інспекції культурної спадщини України щодо здійснення відповідно до закону фотографування, звукозапису, кіно- і відеозйомки, зокрема, з літальних апаратів та із застосуванням космічних технологій.

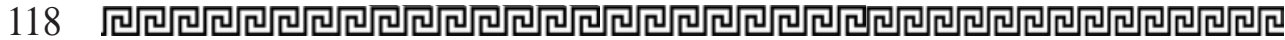


У статті досліджено питання допустимості, належності та достовірності доказів в контексті їх тлумачення в межах цивільного, господарського, адміністративного та кримінального процесів. Конкретизовано правові ознаки даних ДЗз як електронного доказу, зокрема визначення електронного ицфрового підпису як його обов'язкового реквізиту, а також на перспективу передбачено можливість використання інших інструментів криптографічних иифрувань, зокрема приватних ключів в мережі блокчейну. Допустимість розглядається в двох ракурсах, а саме позитивному та негативному. Останній аналізується в контексті ризиків завдання шкоди правам та свободам людини й громадянина, розкриття комериійної таємниці та навіть посягання на національні інтереси в разі неналежного порядку використання даних ДЗЗ. Відповідно, авторами здійснюеться широкий опис національних режимів надання доступу до даних ДЗЗ різної роздільної здатності, особливостей їх експортного контролю, а також специифіки міжнародного-правового регулювання використання космічних знімків. 3 точки зору достовірності досліджувались особливості використання висновку експерта в судовому проце сі будь-якої юрисдикції та висновку спеціаліста в кримінальному процеci. В результаті автори дійшли висновку про необхідність доповнення переліку експертиз аналізом даних ДЗЗ та забезпечення проведення атестації судових експертів. В контексті залучення спеціалістів для надання висновків у кримінальному процесі запропоновано створити перелік акредитованих спеціалістів задля иього, а також передбачити порядок іх взаємодї̈ з правоохоронними органами в КПК України. Крім цього, авторами запропоновано передбачити за спеціальними органами, до повноважень яких нале- жить здійснення нагляду (контролю) за законодавством про охорону культурної спадшини, повноваження щодо збирання даних ДЗЗ як доказів доведення правопорушень у u̧iǔ cфepi.

Ключові слова: аерокосмічний знімок, дані ДЗЗ, допустимість, достовірність.

Malolitneva V., Hurova A. Legal framework for using earth remote sensing data as the evidences for archaeological heritage protection in domestic judicial procedure

The article examines the issues of admissibility, relevance, and reliability of evidence in the context of their interpretation in civil, commercial, administrative, and criminal proceedings. The legal features of remote sensing data as electronic evidence are specified the definition of electronic digital signature as its mandatory details, as well as the possibility of using other cryptographic encryption tools, including private keys in the Blockchain network. Admissibility is considered in two perspectives: positive and negative. The latter is analyzed in the context of the risks of harm to human and civil rights and freedoms, disclosure of trade secrets and even encroachment on national interests in the event of improper use of remote sensing data. Accordingly, the authors provide a broad description of national modes of providing access to remote sensing data of different resolutions, the peculiarities of their export control, as well as the specifics of international legal regulation of the use of space images. From the point of view of reliability, features of use of the conclusion of the expert in judicial process of any jurisdiction and the conclusion of the expert in criminal proceedings were investigated. As a result, the authors concluded that it is necessary to supplement the list of examinations by analyzing 
remote sensing data and ensuring the certification of forensic experts. In the context of involving specialists to provide opinions in criminal proceedings, it is proposed to create a list of accredited specialists for such purposes, as well as to provide for the procedure of their interaction with law enforcement agencies in the Criminal Procedural Code of Ukraine. In addition, the authors propose to provide for a special body, whose powers include the supervision (control) of the legislation on the protection of cultural heritage, the power to collect remote sensing data as evidence of facts on offenses in this area.

Key words: aerospace image, remote sensing data, admissibility, reliability.

\section{Література}

1. Про топографо-геодезичну $i$ картографічну діяльність : Закон України від 23 грудня 1998 р. № 353-XIV. Відомості Верховної Ради України. 1999. № $5 . \mathrm{Cm}$. 46 .

2. Справа від 5 лютого 2019 р. № 676 / 1654 / 17 / Кам’янещь-Подільський міськрайонний суд Хмельницької області. URL: https: / / reyestr.court.gov.ua/ Reviеw/82488711 (дата звернення: 20.11.2020).

3. Справа від 30 червня 2017 p. № $757 / 13206 / 15-$ - / Печерський районний суд міста Kuєва. URL: https: / / reyestr. court.gov.ua/Review/67483878 (Jama звернення: 19.11.2020).

4. Рудика Н. Відповідальність за порушення законодавства у сфері охорони пам'яток археологї. Праці Центру пам'яткознавства. 2011. Bun. 16. C.91-98.

5. Кримінальний кодекс України: Закон України від 5 квітня 2001 р. № 2341 III. Відомості Верховної Ради України. 2001. № 25. Cm. 131.

6. Справа віо 27 червня 2019 р. № 320/2233/19 / Київський окружний адміністративний суд. URL: http: / / reyestr.court.gov.ua/ Reviеw/82753126 (дата звернення: 20.10.2020).

7. Справа від 11 вересня 2018 р. № 909/374/18 / Господар- ський суд Івано-Франківської області. URL: http: / / www.reyestr.court.gov.ua/ Reviеw/76608565 (дата звернення: 20.10.2020)

8. Пільков К. Властивості доказів та критерії ї оцінювання. Підприємництво, господарство і право. 2020. № 4. С. 86-99.

9. Кодекс адміністративного судочинства України : Закон України від 6 липня 2005 р. № 2747-IV. Відомості Верховної Ради України. 2005. №35, 35-36, 37. Cm. 446.

10.Господарський процесуальний кодекс України : Закон України від 6 лисmonada 1991 p. № 1798-XII. Bidoмості Верховної Ради України. 1992. № 6. Cm. 56 .

11. Цивільний процесуальний кодекс України : Закон України від 18 березня 2004 р. № 1618-IV. Відомості Верховної Ради України. 2004. № 40, 40-42. Ст. 492.

12. Кримінальний процесуальний кодекс України : Закон України від 13 квітня 2012 р. № 4651-VI Bidoмості Верховної Ради України. 2013. № 9-10. Cm. 88 .

13. Справа від 27 листопада 2018 p. № 914 / 2505 / 17 / Верховний Суд у складі колегії суддів Касаційного господарського cydy. URL: https: / / verdictum.ligazakon. net/document/78450568 (dama звернення: 25.11.2020).

14. Справа від 28 грудня 2019 р. № 922/788/19 / Верховний Суд у складі колегії суддів Касаційного господарського cydy. URL: http:// reyestr.court.gov. иа/Rеvіеш/86717260 (дата звернення: 25.11.2020).

15. Справа від 26 вересня 2019 р. № 922 / 1151 / 18 / Верховний Суд у складі колегії суддів Касаційного господарського cydy. URL: http:// reyestr.court.gov. иа/Review/84515934 (дата звернення: 25.11.2020).

16. Проєкт Закону про віртуальні активи від 11 червня 2020 р. № 3637. URL: https://w1.c1.rada.gov.ua/pls / zweb2 / webproc4_1?pf3511=69110 (dama звернення: 07.12.2020).

17. Проєкт Закону про токенізовані активи та криптоактиви від 5 листопада 2020 p. № 4328. URL: https: / / 1.c1.rada.gov.ua/pls / zweb2 / webproc4_1?pf3511=70353 (dama звернення: 07.12.2020).

18. Гурова А., Кірпачова М. Правові засади застосування Блокчейн у космічній діяльності: ключові елементи та 


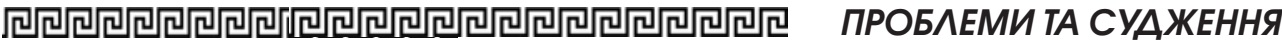

моделі організації. Підприємництво, господарство і право. 2020. № 9. С. 24-30.

19. Тимчасовий порядок використання повітряного простору від 31 травня 2018 р. / Державна авіаційна служба України. URL: https:// ips.ligazakon.net / document / view / FN042940?an=1\&ed=2018_05_31 (Jama звернення: 05.12.2020).

20. Зйомки з використанням дронів: нові обмеження з 1 червня. URL: https: / / imi.org.ua/articles / zjomky-zvykorystannyam-droniv-novi-obmezhennyaz-1-cheronya-i85 (дата звернення: 07.12.2020).

21. Про затвердження Положення про державну систему моніторингу довкілля: Постанова КМУ від 30 березня 1998 р. № 391. Офіціийний вісник України. 1998. № 13.

22. Принципь, касающиеся дистанционного зондирования Земли из космического пространства : приняты резолюиией 41/65 Генеральной Ассамблеи om 3 декабря 1986 г. URL: https:// www.un.org / ru/documents / decl_conv/ conventions / earth_remote_sensing.shtml (дата звернення: 05.12.2020).

23. Coffer M.M. Balancing Privacy Rights and the Production of High-Quality Satellite Imagery. Environmental Science \& Technology. URL: https: / / pubs.acs.org / doi / 10.1021 / acs.est.0c02365\#.

24. Mosteshar S. EO in the European Union: Legal Considerations. Evidence from Earth Observation Satellites: Emerging Legal Issues. Ed. Purdy R., Leung D. Martinus NIJHOFF Publishers, 2013. P. 147-176.

25. Google Street View Opt Put Goes Live in Germany While Spain Investigates. URL: https: / / gigaom.com/2010/08/18/ google-street-view-opt-out-goes-live-ingermany-while-spain-investigates (Jama звернення: 20.10.2020).

26. Candelmo C., Nardone V. Satellite Evidence in Human Rights Cases: Merits and Shortcomings Merits and Shortcomings. Peace Human Rights Governance. 2017. № 1 (1). P. 87-113.

27. Evidence from Space. Study for the European Space Agency on use of spacederived Erath observation information as evidence in judicial and administrative proceedings. London Institute of Space Policy and Law. Final report. 2012. 380 p.

28. Geer $K$. The Constitutionality of Remote Sensing Satellite Surveillance in
Warrantless Environmental Inspections. Fordham Environmental Law Revie. 2011. Vol. 3. No. 1. P. 43-56.

29. Про наиіональну безпеку України : Закон України від 21 червня 2018 р. № 2469-VIII. Відомості Верховної Ради України. 2018. № 31. Ст. 241.

30. Про охорону культурної спадщини : Закон України від 8 червня 2000 р. № 1805-III. Відомості Верховної Ради України. 2000. № 39. Сm. 33.

31. Про інформацію : Закон України від 2 жовтня 1992 р. № 2657-ХII. Відомості Верховної Ради України. 1992. № 48. Cm. 650 .

32. Малищева H. Дистаниійне зондування Землі з космосу - не лише технічна проблема. Правова держава. 2019. Bun. 30. C. 218-229

33. Про топографо-геодезичну $i$ картографічну діяльність : Проєкт Закону України. URL: https://land.gov.ua/ info / proekt-zakonu-ukrainy-pro-topohrafoheodezychnu-i-kartohrafichnu-diialnist (дата звернення: 20.10.2020).

34. Об утверждении Правил планирования космических съемок, получения, обработки и распространения данных дистанционного зондирования Земли нацииональным оператором космической системы дистаниионного зондирования Земли: Постановление Правительства Республики Казахстан от 31 мая 2012 2. № 722. URL: https:// tengrinews. kz/zakon / pravitelstvo-respublikikazahstan-premer-ministr-rk/nauka/ id-P1200000722.

35. Бек М. Національне регулювання діяльності дистаниійного зондування Землі з космосу у країнах, що розвиваються (на прикладі Індї та Казахстану). Науковий вісник Міжнародного гуманітарного університету. Серія: Юриспрудениія. 2015. № 16. T. 2. С. 133-136.

36. Summary report 2018. Our remit, responsibilities and results. Federal Office for Economic Affairs and Export Control. URL: https: / / www.bafa.de/SharedDocs / Downloads/EN/Federal_Office/bafa_ abridged_annual_report_2018.html (dama звернення: 21.10.2020).

37. National Data Security Policy for Space-Based Earth Remote Sensing System. Background Information for the Act on Satellite Data Security. Federal Ministry of Economics and Technology. URL: https: / / www.bmwi.de / Redaktion / DE / Downloads / S-T / satdsig-hintergrund-en. 


\section{ЮРИАИЧНИЙ ВІСНИК, 2020/6}

pdf?_blob=publicationFile $\& v=1$ звернення: 20.10.2020)

38. GMES data security policy and German experiences in the national satellite data security policy. URL: https:// ec.europa.eu/docsroom/documents / 630/ attachments / 1 / translations / en / renditions / native $+\& c d=1 \& h l=r u \& c t=c l n k \&$ $g l=и а$ (дата звернення: 30.10.2020).

39. Малишева Н., Гурова А. Новашії в дозвільному порядку здійснення космічної діяльності: об'єктивна необхідність ии данина часу? Космічна наука і технологія. 2016. T. 22. № 6. С. 37-44.

40. Is imagery from Google Earth Admissible in Court? URL: https:// advantageinvestigators.com/google-earthadmissible-in-court (дата звернення: 07.12.2020)

41. Ткаченко О., Баранова Т. Підходи щодо валідації $i$ верифікації програмного забезпечення обробки супутникових даних для агромоніорингу. Енергетика і автоматика. 2018. № 4. С. 75-82.
42. Should we always trust what we see in satellite images? URL: https: / / wrw. scientificamerican.com / article/shouldwe-always-trust-what-we-see-in-satelliteimages (дата звернення: 07.12.2020).

43. Ito A. Legal Aspects of satellite remote sensing. Martinus Nijhoff Publishers. 2011. $353 p$

44. Про деякі питання практики призначення судової експертизи : Пленум Вищого Господарського суду України від 23 березня 2012 р. № 4. Вісник господарського судочинства. 2012. № 3.

45. Про затвердження положень про деякі иентральні органи виконавчої влади у сфері культури та внесення змін до Положення про Міністерство культури, молоді та cпорту України : Постанова КМУ від 24 грудня 2019 р. № 1185. Офіиійних вісник України. 2020. № 19.

46. Про затвердження Положення про Державну екологічну інспекцію України : Постанова КМУ від 19 квітня 2017 р. № 275. Офіційний вісник України. 2017. № 36. 